\title{
The Role Of Thein Improving The Conseleempaty In Family Members
}

\author{
Heppi Sasmita', Neviyarni S2, Yarmis Syukur ${ }^{3}$ \\ 1 Poltekkes Ministry of Health Padang, Indonesia \\ 2 Padang State University, Indonesia \\ 3 Padang State University, Indonesia
}

Corresponding Author $\otimes$ heppisasmita@yahoo.com

\begin{tabular}{cl}
\hline & \multicolumn{1}{c}{ ABSTRACT } \\
\cline { 2 - 3 } ARTICLE & $\begin{array}{l}\text { Every family wants harmony in the family. Awareness of the role and } \\
\text { function of accepting circumstances and existence is a very strong } \\
\text { foundation in running a household. In realizing a harmonious household, } \\
\text { of course there are problems that must be resolved immediately so that } \\
\text { family harmony is maintained and realized. The family has an important } \\
\text { Article history: } \\
\text { role in the success of the child, remembering that most of the time in the } \\
\text { child's daily life with the family, the family is the first community for the } \\
\text { child to interact. But in this digital era, many people of all ages have really } \\
\text { changed. Changing to be fast paced, but also decreasing the harmony that }\end{array}$ \\
05 Mei 2021 & $\begin{array}{l}\text { has been established in the family, this can be seen by the reduced love, } \\
\text { cooperation and sharing in the family because they are busy with their } \\
\text { respective activities, especially when dealing with gadgets so that }\end{array}$ \\
Accepted & $\begin{array}{l}\text { harmony in the family is reduced. The role of school counselors is } \\
\text { indispensable in forming empathy for family members to achieve } \\
\text { household harmony by using family counseling, which is used as an } \\
\text { intervention process for problems that interfere with family harmony. }\end{array}$ \\
& $\begin{array}{l}\text { Family counseling seeks to build closer bonds, individuals who are able to } \\
\text { control emotions, and families who always have good communication in } \\
\text { realizing family harmony. }\end{array}$ \\
\cline { 2 - 3 } Key Word 2021 & $\begin{array}{l}\text { Counselor, Empaty, Family. } \\
\text { Heppi Sasmita, Neviyarni S, Yarmis Syukur, (2021). The Role Of Thein }\end{array}$ \\
How to cite & $\begin{array}{l}\text { Improving The Conseleempaty In Family Members. Journal Of Education } \\
\text { And Teaching Learning (Jetl). }\end{array}$ \\
\cline { 2 - 3 }
\end{tabular}

\section{INTRODUCTION}

Current problems related to the humanitarian aspect or concern for fellow human beings are felt to be decreasing. This happened in line with the swift currents of modernization, which hit almost all corners of the region. As a result, developing life tends to be very individualistic, less motivated in sharing the suffering of others, a culture of very low concern. The statement basically gives an indication of a lack of empathy for a person (individual). In general, empathy is defined as a part of psychic life, which is the movement of one's heart and mind towards the psychological situation and condition of others. In this case, the feeling of empathy can be done as long as a person has the will to feel everything that is felt by other people (fellow), anytime and anywhere. Therefore, empathy is very necessary in everyday life, because feelings of empathy can foster a deep sense of concern for others. The consequence is 
that humans who lack or even do not have an attitude of empathy will be indifferent or tend to behave as they please, do not care about the circumstances of their fellow human beings, and have no sensitivity to the lives of their fellow human beings. This attitude is currently owned by some families in our life.

A harmonious life cannot be separated from social interactions, both interactions with older people and interactions with peers, according to technological developments, there are many factors that can be used as interaction tools today, such as Android-based cellphones, laptops, and other communication tools through social networks. Facebook, whatsapp, Instagram, twitter, etc. But the existence of these communication tools actually raises new problems today where family members rarely communicate directly such as when eating together, joking while at home, discussing and sharing experiences and so on, but what happens is the opposite because they are busy with gadgets their respective. In the end, there is no harmony in the family.

Family is a place of shelter, shelter, sharing emotions and affection, and there are many more positive things that can be obtained in the family, today has changed a lot. Family functions and roles are increasingly varied and increasingly dependent on parents' daily activities. Parents who have a proportion of activities outside the home decrease their capacity to make family a priority. To restore the functional meaning of the family with the impact of digitization and the activities of all family members, the school as an agent of change with an interest in educating students (family members) in totality must find an accurate strategy. According to (Gunarsa, 2000) that is if all family members feel happy which is marked by reduced tension, disappointment and acceptance of all circumstances and their existence (existence, self-actualization) which includes physical, mental and social aspects. In creating family harmony, awareness of roles and functions in the family becomes something that must be realized and understood, the attitude of accepting the situation and existence in a family becomes a strong foundation in running the household. The family must be based on love, mutual understanding, full of love, harmony and peace.

Based on the explanation of the problems above, the counselor's role is needed in increasing family empathy. The existence of this role will help the family in solving the problem solving that occurs. Counselors are a solution because they have advantages that can increase family empathy. The hope is that after being given guidance by the counselor, it can change the empathy of the family to be better, friendly, foster cooperation and high solidarity among others.

\section{RESEARCH METHODS}

This research uses a library research type, namely research in which the data are obtained from literature studies or related literature, then analyzed theoreticallyphilosophically, concluded and raised by relevance and contextualization. The approach used is a phenomenological approach to see how the role of the counselor in increasing family empathy so that the goals of the counseling guidance carried out by the counselor are achieved effectively, efficiently and productively. 


\section{DISCUSSION}

\section{A. Family Guidance and Counseling}

Guidance is an assistance provided by supervisors to individuals who need guidance by providing direction to these individuals to find and develop their potential in solving a problem without any element of coercion. Prayitno argues that guidance is a process of providing assistance carried out by an expert person to one or several individuals, both children, adolescents and adults so that the person being guided can develop their own abilities by utilizing individual strengths and existing facilities and can be developed based on norms. - applicable norms. (Hamdani, 2012).

Meanwhile, according to Winkel counseling as a series of the most basic activities and guidance in an effort to help the counselee or client face to face with the aim that the client can take responsibility for himself on various problems and special problems. (Intan, 2019). While family guidance and counseling is a process in an effort to provide assistance by counselors in helping each family member realize the duties, roles, and functions of each family member so that they understand each other and create harmony in the family and avoid conflicts in the family.

According to Vincent, family counseling is "... the attempt to modify the relationship in a family to achieve harmony." That is, family counseling is assistance intended to change the relationships that are not harmonious in a family so that the family achieves more harmonious relationships. (Kustiah, 2016). Family counseling or family counseling is an effort of assistance given to individual family members through the family system (improvement of family communication) so that their potentials develop optimally and can overcome problems faced on the basis of the willingness to help from all family members based on their willingness and love for family. (Sofyan Willis, 2009). So family counseling is in the form of assistance by counselors to alleviate problems that occur in the family by improving family communication and changing disturbed family functions together so that all family members remain harmonious.

Family counseling aims to improve the functioning of the family system more effectively. In particular, family counseling aims to help family members gain awareness about relationship patterns that are not functioning properly and create new ways of interacting to overcome the problems they face. On the other hand, family counseling also has the aim of focusing on solving specific problems that cause families to ask for counseling assistance from a counselor (Nurhayati, 2011).

The process of family counseling is different from individual counseling because it is determined by various factors such as the number of clients (family members) more than one. Relationships between family members are very diverse and emotional, and counselors must be involved (full participants) in the dynamics of family counseling. Based on the fact, there are five types of relationships or relationships in family counseling, namely: 1) the relationship between a counselor 
and the counselee, 2) the relationship between one counselee and another counselee, 3) the relationship between the counselor and the group, 4) the relationship between the counselor and the whole family and, 5 ) relations between groups as well as other groups of members, for example, mothers sided with sons and fathers sided with daughters.

Broadly speaking, theories in counseling are divided into threegrand theories, namely as follows:

1. Psychodynamic Approach

This theory represents the main tradition in contemporary counseling and psychotherapy. Psychodynamic counseling pays great attention to the counselor's ability to use what happens in the immediate and open relationship between the client and the counselor, to explore the types of feelings and relationship dilemmas that cause difficulties for the client in his daily life.

The purpose of this counseling is to help clients reach awareness and understanding of the reasons behind the problem, then translate this awareness into mature abilities to deal with various problems in the future. For this process to work, the counselor needs to be able to offer the client a sufficiently safe and consistent environment in which the client can safely express painful or embarrassing fantasies and urges. (Mansour, 1999).

The figure of this theory is Sigmund Freud, where the method of treatment is called psychoanalysis. According to Freud, the unconscious is that part of a person's mental life that is outside direct awareness. In his view, Freud divided the human mind into three areas, namely: a) The id is a container for personality instincts, motives, desires that must be fulfilled regardless of the time and environment that is important for enjoyment to be achieved, b) the ego, functions as a mediator between the superego and the id which is the rational part that makes decisions and relates to the outside world, c) the superego, is a moral that allows or does not do something (John, 2010). Between the three, the id, ego and superego are often incompatible and often cause controversy in one's personality, for this reason, self-defense mechanisms emerge in the form of: a) Repression, motivated by forgetfulness, b). Deniel (rejection), c) Projection is attributed to a person's unacceptable desires or thoughts, d) Displacement (redirection of impulses): linking impulses (usually aggressive drives) to different targets, e) Reaction formation (judging the opposite party) ): defend oneself from unacceptable impulses by turning them into opponents, f) Sublimation, finding acceptable substitutes: transforming drives into more socially acceptable forms of behavior, g) Regression (developmental decline): responding to internal feelings triggered by external threats by repeating childish behavior from an earlier developmental stage (Allen, 1980).

2. Behaviorism

Approach This approach is derived from behavioral psychology (behavior) and has three characteristics, namely:problem solving, a change focusedapproachto 
dealing with clients, respect for scientific values; and have more attention to cognitive processes - tools to control and monitor their behavior. The characters are Pavlov, Skinner, Seligmen. (John, 2010). If the behavioral counselor assists the client, there is a relevant change in the client's behavior. Some of the basic techniques commonly used in behavioral counseling are as follows: a) Relaxation exercises, there are two kinds of relaxation, namely emphasis on contrast relaxation and direct relaxation, b) Modeling; c) Reinforcement or positive reinforcement, d) Charting, which is making a measure of the distance with changes in behavior by the client before, during and after therapy. This technique can be used for family communication exercises, keeping the room clean, smoking cessation programs. (John, 2010).

3. Approach to Humanism

This theory emerged because of the dissatisfaction of the two previous theories, namely psychodynamics and behaviorism. In counseling and psychotherapy, the most widely used humanistic approach is the personcentered and Gestalt approach. The composition that is common in all humanistic approaches is the emphasis on experiential processes. The main concern of Rogers and other person-centered theorists is to develop an effective approach, not to engage in theoretical speculation. One of the unique characteristics of the person-centered image is its attempt to describe afully functioning person. The three compositions of the therapeutic relationship that tend to attract the most attention in person-centered education and research are the quality of counselor acceptance, empathy and authenticity (John, 2010).

There are several models of family counseling, including family therapy (family therapy). This therapy began to emerge and develop since the 1950s. The method used in family therapy uses a structural approach in dealing with family problems. The starting point of this approach is the opinion that the family is the smallest social system. So in essence, if one family member experiences problems that interfere with his mind and balance or appearance of behavior (behavioral deviation) then the rest of the family will also follow the disturbance or shock (Willis, 2009). The steps in Guidance and Counseling are as follows:

1. Identification of cases. This step is intended to identify cases and the symptoms that appear. In this step the supervisor records the cases that need guidance and selects which cases will receive assistance first.

2. Diagnosis. This step is to determine the problem at hand and the case and its background. In this step, the activities carried out are collecting data by conducting case studies using various data collection techniques, then determining the problems encountered and their backgrounds.

3. Prognosis. This step is to determine what type of assistance or therapy will be carried out to guide the case based on the conclusions in the diagnostic step. 
4. Therapy. The therapeutic step is the implementation step of assistance or guidance. This step is the implementation specified in the prognosis.

5. Evaluation andSteps Follow Up. This step is intended to assess or find out to what extent the therapeutic steps that have been carried out have achieved results. In the follow-up or follow-up steps, further developments are seen in a longer period of time. (Elis, 2013).

According to (Mubarok, 2009) the ideal partner of the word family is happy, this means that the goal of everyone is to build a household mahligai to seek happiness in life. Almost all societies place family life as a measure of true happiness. Even if a person fails in his career outside the home, but succeeds in building a strong and prosperous family, he is still seen as a successful and happy person. On the other hand, people who are successful outside the home, but whose family is in disarray, are not called lucky people, because they have succeeded in building a happy family.

\section{B. The Importance ofBetween Family Members}

EmpathyEmpathy in the family is very important, with empathy making family relationships close. One of the problems that often arises is the lack of empathy in communication which can lead to misunderstandings between families. Empathy is defined as a feeling of sympathy and concern for others, especially to share experiences or indirectly feel the suffering of others. (Asih, 2010). According to Baron and Byrne, empathy is the ability to feel the emotional state of others, feel sympathetic and try to solve problems, and take the perspective of others. (Rizki, 2019). Furthermore, empathy has an important role in the development of social understanding, positive social behavior and serves as the foundation of relationships and becomes the basis for conflict resolution (Barr and Higgins, 2009).

Empathy is expressed that identification with someone appears to some extent in every conversation, even empathy is a fundamental process in love (Enjang, 2009). Baron and Byrne state that in empathy there are the following aspects: a) Cognitive, is an individual who has the ability to empathize with what other people feel and why it can happen to that person. b) Affective, namely individuals who empathize feel what other people feel. While in empathy there are also several aspects, namely: a) Warmth, is a feeling that a person has to be warm towards others, b) Tenderness, is a feeling that a person has to behave or speak softly towards others, c) Caring, is an attitude that a person has to give attention to others and the surrounding environment. (Asih, 2010).

The causes of low communication between parents and children can be seen from the lack of communication time, causing harmony in the family to decline, a relatively lasting family, marked by attention, honesty, openness, supportive attitude, positive sense and strong cooperation in family members, making a family that is strong. harmonious. In this case, of course, the role of parents is demanded in giving empathy to the family so that a harmonious family is created. According to (Gunarsa, 2000) the atmosphere of the house can affect family harmony to be 
pleasant and the creation of mutual understanding, harmonious cooperation and mutual love for one another, in addition, children can feel that their parents want to understand and can live up to their behavior patterns, can understand what they are doing. he wants, and gives affection wisely, feels that his brothers want to understand and respect him according to his wishes, pleasures and ideals, and the child can also feel the love given by his brothers.

\section{The Counselor's Role in Increasing Empathy for Family Members The}

Family is a system, as a family system has members, namely; father, mother and child or all individuals living in the household. Family members interact with each other, interrelation and interdependence to achieve common goals. The family is an open system so that it can be influenced by the supra system and vice versa as a subsystem of the environment (society) the family can affect society (supra system). Therefore, how important is the role and function of the family in forming family harmony.

Lack of family understanding of the importance of education can cause a family crisis, meaning that family life is in a state of chaos, disorder and direction, parents lose the authority to control the lives of their children, especially teenagers. There are several factors that often occur as the cause of family crises, namely:

1. Egocentrism

2. Economic problems

3. Problems with the busyness of each family member

4. Low education

5. problemsInfidelity problems

6. Lack of understanding in religious teachings

7. Lack of communication between every family member, especially parents.

Some of the problems above must have a way out and solve them. There is a traditional way and there is also a modern way or what is often called the scientific way. Solving family problems in the traditional way is divided into two parts, namely: 1) Wisdom or by means of affection, kinship, 2) Parents in solving family crises, especially those related to problems with children and wives. While the scientific way by way of family counseling (family counseling). This method is what counseling experts have done. There are two approaches, namely: 1) an individual approach called individual counseling, namely an effort to explore the emotions, experiences and thoughts of family members as clients in the implementation of counseling, 2) a group approach (family counseling). This way by discussing in the family guided by a family counselor. In the life of society everywhere, the family is the smallest unit whose role is very large and urgent. This very large role is due to the family which has a very important function for the survival of society. If the function of the family does not go well, then there is a mismatch in the relationship between family members, it can be said that the family has a problem. The existence of individuals (families) who have problems, it is necessary to have Guidance and Counseling to seek prevention or provide assistance in solving the problem. 
According to (Nofrianti, 2020) the role of the counselor in helping clients with family and marriage counseling was stated by satir (Cottone, 1992) including the following:

1. The counselor acts as a "facilitative a comfortable", helping clients see clearly and objectively themselves and their actions. alone.

2. Counselors useskills treatment through setting interaction roles.

3. Trying to eliminate self-defense and family.

4. Teach clients to act maturely and to be responsible and exercise self-control.

5. Counselors mediate conflicts or communication gaps and interpret messages conveyed by clients or family members.

6. The counselor resists judgmental acts and helps establish congruence in family members' responses.

Counselors can assist families in guiding children appropriately, both in the learning process at school and in the behavior of children in everyday life and in this case of course the counselor must cooperate with parents in order to get good results.

Guidance and counseling involve the family not only in consultation but in the counseling process the family is involved in it, so that family counseling is carried out that is able to change or increase the potential and development of children by involving all family members, by building relationships and communication in a family counseling activity. Family counseling for children who lack family empathy certainly requires the role of a counselor. The existence of the counselor in guiding the family serves to neutralize all his actions. Without the help of a counselor, the family is always confused, restless, indecisive, and so on. As a result, the family is not able to get the meaning of happiness and prosperity in life. Mental conditions that are not calm can be categorized as mental disorders or in terms of psychopathology called neurosis. Human life does not always go straight, sometimes shocks are present in the steps of life that are lived.

\section{CONCLUSIONS}

Counseling is an effort made by the counselor to the counselee to facilitate changes in the counselee's behavior which leads to overcoming the problems at hand. A harmonious relationship begins with the formation of effective communication. Empathy is one way to form effective communication. Empathy can be developed with a variety of supportive skills. Such skills including influencing skills (Influencingskills) such disclosure (self-disclosure), direction (directive) and interpretation (interpretation). With this, empathy will be deep and accurate and of high value so that it can immediately change the problems that occur.

\section{REFERENCES}

Amalia, Rizki, Empathy as the basis of the counselor's personality, Journal of Education and Counseling Research \& Learning in the Faculty of Education, Vol. 1 No. 1, 2019. 
Barr, JJ \& Higgins, A. How Adolescent Empathy and Prosocial Behavior Change In The Context Of School Culture A Two-Year Longitudinal Study. Journal. Adolescence. 44. 176. Academic research Library, 2009.

Enjang, (2009), Counseling Communication. Bandung: Shades.

Faqih, Mansour, (1999), Gender Analysis and Social Transformation, Yogyakarta: Pustaka Pelajar.

Gunarsa, SD, (2000), Psychology for the Family. Jakarta: Mount Mulia.

Gusti Y. Asih, \& Pratiwi Mageretha MS Prosocial Behavior in terms of Empathy and Emotional Maturity. Journal of Psychology, Muria Kudus University. Vol.1 No.1. 2010.

Hamdani. (2012). Guidance and Counseling. Bandung: Faithful Library.

Intan Asti Purnamasar, Family Counseling Guidance Services To Minimize Divorce Rates, Journal of Islamic Guidance, Counseling, Counseling, and Psychotherapy Vol. 7, No.1, 2019, 41-60 ISSN : 2086-4116 (Print) DOI : 10.15575/IRSYAD.V7I1.884.

John Mc Leod, (2010), Introduction to Counseling, Theory, and Case Studies, Jakarta: Kencana.

Muawanah, Elis \& Yusria Ningsih, Family Counseling Guidance with Loving Kindness Therapy in Improving Emotion Regulation, Journal of Islamic Guidance and Counseling Vol. 03, No. 02, 2013.

Mubarok, Achmad, (2009), Family Psychology: From the Sakinah Family to the National Family, Jakarta: Wahana Aksara Prima.

Noffiyanti, Realizing Household Harmony Using Family CounselingCounseling, Al-Ittizaan: Journal of IslamicGuidance ISSN: 2723-021X. Vol.3, No.1, 2020, pp. 8-12.

Nurhayati, Eti, (2011), Counseling Guidance and Innovative Psychotherapy, Yogyakarta: Student Library.

Sunarty, Kustiah \& Alimuddin Mahmud, (2016), Marriage and Family Counseling, Makassar: Makassar State University Publishing Agency.

Tasmara, Toto, (2001), Spiritual Intelligence, Human Echo: Jakarta. Willis, Sofyan S., (2008), Family Counseling, Bandung: Alfabeta. 